\title{
CAPYBARAS IN AN ANTHROPOGENIC HABITAT IN SOUTHEASTERN BRAZIL
}

\author{
VERDADE, L. M. and FERRAZ, K. M. P. M. B. \\ Laboratório de Ecologia Animal, Departamento de Ciências Biológicas, Escola Superior de Agricultura "Luiz de Queiroz", \\ Universidade de São Paulo, C. P. 09, CEP 13418-900, Piracicaba, SP, Brazil \\ Correspondence to: Luciano M. Verdade, Laboratório de Ecologia Animal, Departamento de Ciências Biológicas, \\ Escola Superior de Agricultura "Luiz de Queiroz", Universidade de São Paulo, \\ C. P. 09, CEP 13418-900, Piracicaba, SP, Brazil, e-mail: lmv@esalq.usp.br
}

Received February 26, 2004 - Accepted April 16, 2004 - Distributed 28 February, 2006

(With 1 figure)

\begin{abstract}
Capybaras (Hydrochoerus hydrochaeris) are widely distributed in the Neotropics, living in both natural and anthropogenic habitats. In the present study, we monitored the fluctuating capybara population at the Campus "Luiz de Queiroz", University of São Paulo, in Piracicaba, Southeastern Brazil from 1998 to 2000. To assess population fluctuation and growth rates, we used an abundance index based on direct weekly daylight counts. Population monitoring was carried out in an anthropogenic wetland associated with an agroecosystem. The observers' bias was established as directly related to their distance from the animals. The capybara population density and biomass in the anthropogenic wetland in question were found to be significantly higher than in pristine habitats. The species seems to present a seasonal pattern of fluctuation, with a peak in late spring (Oct to Dec). Unlike young capybaras, adults and juveniles present similar seasonal fluctuation patterns. In this anthropogenic wetland, the carrying capacity may be as high as 195 individuals $/ \mathrm{Km}^{2}$. At a conservative exploitation rate (17\%) in anthropogenic wetlands of Southeastern Brazil, capybara productivity may reach approximately $630 \mathrm{Kg} / \mathrm{Km}^{2} /$ year.
\end{abstract}

Keywords: agroecosystem, biomass, carrying capacity, Hydrochoerus hydrochaeris, population fluctuation.

\section{RESUMO}

\section{Capivaras em um habitat antrópico no Sudeste do Brasil}

Capivaras (Hydrochoerus hydrochaeris) distribuem-se amplamente na região neotropical em habitats naturais e antrópicos. No presente estudo, a flutuação populacional de capivaras foi monitorada no Campus "Luiz de Queiroz" da Universidade de São Paulo, em Piracicaba, Região Sudeste do Brasil no período entre 1998 e 2000. Para avaliar a flutuação populacional e suas taxas de crescimento, foi usado um índice de abundância baseado em contagens diurnas semanais. O monitoramento foi conduzido em uma área de várzea antrópica. $\mathrm{O}$ viés de observadores foi avaliado, sendo diretamente proporcional à sua distância em relação aos animais. A densidade populacional e biomassa de capivaras na área antrópica estudada foram significativamente maiores do que em habitats naturais. A espécie apresentou um padrão sazonal de flutuação com pico no final da primavera (outubro a dezembro). Adultos e juvenis apresentaram padrões de flutuação sazonal similares, diferindo do apresentado por filhotes. Neste habitat de vázea antrópica, a capacidade de suporte foi de aproximadamente 195 indivíduos $/ \mathrm{Km}^{2}$. Para uma taxa de extração conservadora (17\%) em várzeas antrópicas da Região Sudeste do Brasil, a produtividade de capivaras pode alcançar cerca de $630 \mathrm{Kg} / \mathrm{Km}^{2} /$ ano.

Palavras-chave: agroecossistemas, biomassa, capacidade de suporte, flutuação populacional, Hydrochoerus hydrochaeris. 


\section{INTRODUCTION}

The capybara (Hydrochoerus hydrochaeris) is the world's largest living rodent and occurs in a variety of habitats such as gallery forests and seasonally flooded savannas (Moreira \& Macdonald, 1997). The species is widespread in the Neotropics, ranging from Central America to Buenos Aires Province in Argentina (Ojasti, 1973; Azcárate, 1980; Eisenberg \& Redford, 1999).

Capybara is one of the species with the greatest potential for sustainable use in South America due to the following characteristics: high growth rate ( $45 \mathrm{Kg}$ at the age of two years), high reproductive rate (six young/female/year); and relatively high sociality (Ojasti, 1991; Lord, 1994; Moreira \& Macdonald, 1996; 1997; Macdonald, 1999). However, capybara hunting is illegal in most countries where the species occurs, with the exception of Venezuela, Peru, Suriname and some provinces of Argentina (Ojasti, 1991).

In the province of Corrientes, Argentina, controlled hunting of capybaras is allowed when crop damage is officially identified (Ojasti, 1991). In the Venezuelan llanos, a legal hunting program initiated in 1968 reached an estimated exploitation rate of $30 \%$ of the total population in areas where the species is abundant (Ojasti, 1973; 1991; González-Jiménez, 1984). However, Herrera \& Moreira (1996) consider this hunting pressure too high, since wild populations have shown a dramatic decline in many regions of Venezuela over the last 20 years. Lord \& Lord (1988) verified a reduction of $27.63 \%$ of the capybara population in the Venezuelan llanos associated with agricultural harvests. Moreira \& Macdonald (1996) suggested that the annual exploitation rate should be $17 \%$. According to them, this rate would be closer to the maximum sustainable yield and could generate $841 \mathrm{Kg} / \mathrm{Km}^{2} /$ year, although net production and sustainable exploitation rates may vary from one area or population to another due to local conditions and population levels. According to Kleiman et al. (1979), even in low population densities resulting from overexploitation, capybaras may produce more biomass per area than Agouti, Dasyprocta and Proechimys - three common forest-dwelling caviomorph rodents - combined.

In recent years capybaras have reportedly caused damage in experimental agricultural fields at the Campus "Luiz de Queiroz", University of São Paulo, in central-eastern São Paulo state (Ferraz et al., 2003). In order to establish a management program, we have been monitoring the capybara population on campus since July 1998. Based on models that take into account the population fluctuation, we aim to establish a sustainable management program in which the population is kept below damage level and as close as possible to the maximum sustainable yield. The "Luiz de Queiroz" campus presents a mosaic landscape comprising a mixed agroecosystem, which is typical of much of the countryside of the state of São Paulo. For this reason, we believe these results may serve as a basis for the establishment of similar programs in other areas of the state.

\section{STUDY AREA}

Campus "Luiz de Queiroz", University of São Paulo, (22 42'30” S, 47 38'30” W, 546 m of average altitude) is located in Piracicaba, centraleastern region of the state of São Paulo, Brazil. The campus covers approximately 860 ha and comprises agricultural fields, exotic pastures (mostly Panicum maximum), forest plantations (mostly Pinus sp. and Eucalyptus sp.), wetlands, and fragments of semideciduous native forest.

The capybaras can be found in most of the campus, especially near water bodies and agricultural fields. In the present study, we monitored fluctuation of the the capybara population on an anthropogenic wetland (12.9 ha) surrounded by an exotic pasture (Panicum maximum) (21.1 ha) and a depauperate fragment of gallery forest (6.9 ha) in a total area of 40.8 ha.

\section{METHODS}

We established an abundance index based on direct counts of animals during the last two hours of sunlight. At that period of the day, the animals usually forage in open areas and are more detectable (Ojasti, 1973; Schaller \& Crawshaw, 1981; Herrera, 1986; Jorgenson, 1986; Alho et al., 1989; Cordero \& Ojasti, 1989; Mourão \& Campos, 1995). This method is widely used for the species in open areas, especially during the dry season.

Ecological density (sensu Eisenberg \& Seidensticker, 1976:297) was calculated for the 40.8 ha area where direct or indirect evidence of 
the species (e.g., feces, tracks, or animals) were present. Ecological density is the density of a species in the macro habitats in which it normally occurs. Ecological density values were compared between age classes by the Kruskal-Wallis test (Sokal \& Rohlf, 1995). For this purpose, based on body sizes we considered three ages: adults (above $30 \mathrm{Kg}$ ), juveniles (from 10 to $30 \mathrm{Kg}$ ), and young (below $10 \mathrm{Kg}$ ). Though somewhat arbitrary and subjective, such classification is sufficiently robust not to require much observer training and skills. Animal counts were repeated on a weekly basis from July 1998 to November 2000 by no more than three observers at a time. Observers counted the animals individually while walking around the site's main water body.

Observer bias was evaluated in relation to their distance from the animals. Three different observers did 20 simultaneous unshared daily counts (July-August 2000) at three different distance ranges from the groups of animals $(<10 \mathrm{~m}$, from 10 to 50 , and from 50 to $100 \mathrm{~m}$ ). The results were compared by T Test (Zar, 1996).

An abundance index does not indicate the total population size, but only the maximum number of individuals seen at a specific site at the same time, which can be defined ideally as the minimum immediate population size at the time of the observation. However, we can often assume that there is a strong correlation between the abundance index and the real population size at that time (Caughley, 1977; Conroy, 1996; Greenwood, 1996; Lancia et al., 1996). The abundance index is related to the observer's capacity to detect the animals on the site, which is usually influenced by the density and type of vegetation.

We fit population fluctuation to mathematical models, taking into account a period of high growth rate (Brown \& Rothery, 1993; Murray, 1993). The data were subjected to a "trend analysis" (Minitab, 2000), which fits a general trend model (linear, quadratic, exponential, or asymptotic) to time-series data and provides forecasts. The models were chosen based on their accuracy estimated by their mean squared deviation (MSD). This is similar to the mean squared error but, since it uses the same denominator (n) regardless of the model, it can be compared across models. Slopes of similar curves were compared by Analysis of Covariance (Zar, 1996:362), where the basic calculations necessary to compare different regression lines require the total sum of squares, the residual sum of squares, and the degrees of freedom for each computed line. The rate of increase $(r)$ and carrying capacity $(k)$ - generated by the models - are presented and discussed as a basis for a sustainable management program (as suggested by Caughley, 1977 and Caughley \& Sinclair, 1994).

\section{RESULTS}

The average abundance index of the population was $50.55 \pm 1.81$ (mean \pm standard error of mean) individuals. Considering the aforementioned surveyed area, the ecological density was $124 \pm$ 4 individuals $/ \mathrm{Km}^{2}(1.24 \pm 0.04$ individuals $/ \mathrm{ha})$ in 40.8 ha. Based on an individual average body mass of $30 \mathrm{Kg}$ (Ojasti, 1973; Eisenberg et al., 1979; Schaller, 1983), the estimated biomass was 3720 $\pm 120 \mathrm{Kg} / \mathrm{Km}^{2}$ (Table 1$)$.

The peak number of individuals occurred at late spring (Oct to Dec) (Fig. 1). 1999 population fluctuation data were fit to mathematical models by Times Series Analysis (Minitab, 2000) because they presented a high growth rate in that period, reaching a plateau that could be assumed to be an estimate of the habitat's carrying capacity. Adults and juveniles

\section{TABLE 1}

Abundance index, ecological density and estimated biomass of capybaras on an anthropogenic wetland at the Campus “Luiz de Queiroz", University of São Paulo, in Piracicaba, southeastern Brazil (mean \pm standard error of mean).

\begin{tabular}{|l|c|c|c|}
\hline & Abundance index (ind) & Ecological density (ind/Km $\left.{ }^{2}\right)$ & Estimated biomass* $\left(\mathbf{K g} / \mathbf{K m}^{2}\right)$ \\
\hline Total population & $50.55 \pm 1.81$ & $124 \pm 4$ & $3720 \pm 120$ \\
\hline Adults & $29.96 \pm 1.27$ & $73 \pm 3$ & - \\
\hline Juveniles & $10.89 \pm 0.59$ & $26 \pm 1$ & - \\
\hline Young & $9.70 \pm 0.51$ & $24 \pm 1$ & - \\
\hline
\end{tabular}

*Individual average body mass: $30.0 \mathrm{Kg}$ (Eisenberg et al., 1979; Schaller, 1983). 

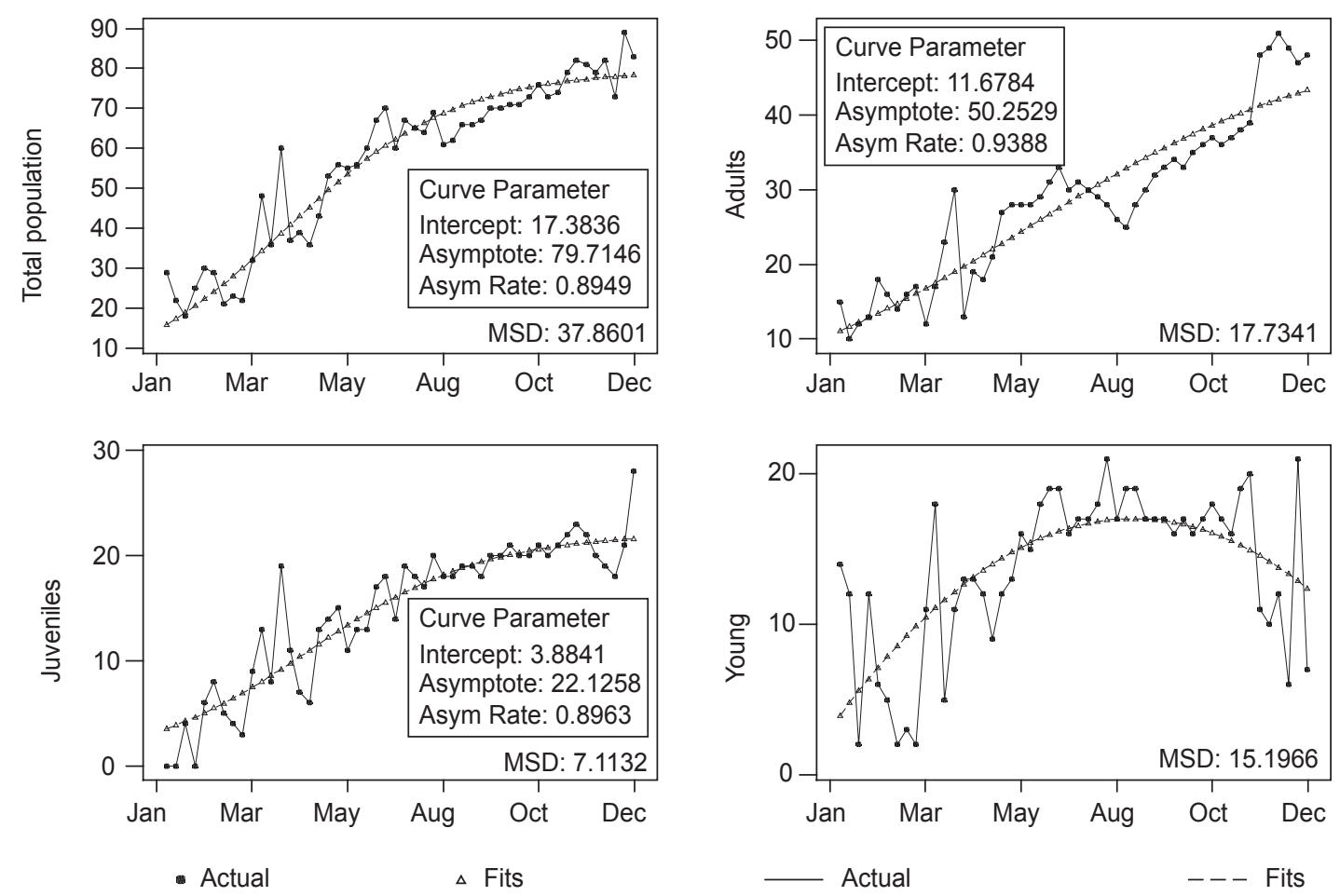

Fig. 1 - Population growth curves for adults, juveniles and young during 1999 (MSD: Mean standard deviation).

presented asymptotic curves, as did the total population, but young presented a clear quadratic model (Fig. 1), indicating that the reproductive rate may have reached the carrying capacity but that the size distribution was not stable.

The carrying capacity $(k)$ and rate of increase $(r)$ generated by the model for the total population were, respectively, 79.71 (195 individuals $/ \mathrm{Km}^{2}$ ) and 0.89 . For adults, $k=50.25$ (123 individuals $/ \mathrm{Km}^{2}$ ) and $r=0.94$; and for juveniles $k=22.12$ (54 individuals $/ \mathrm{Km}^{2}$ ) and $r=0.89$. The maximum value of abundance index for young generated by the quadratic model was approximately 17 individuals (41 individuals $/ \mathrm{Km}^{2}$ ).

Differences among observers were not detected when they were positioned close $(<10 \mathrm{~m})$ to the animals. However, at greater distances (10 to $100 \mathrm{~m}$ ), the observers' counts differed significantly from each other (T Test, $\mathrm{p}<0.001$ ) (Table 2).

\section{DISCUSSION}

The present study found that the ecological density and biomass for this anthropogenic habitat associated with an agroecosystem were significantly higher than in Brazilian Pantanal (respectively, from 1 to 69 individuals $/ \mathrm{Km}^{2}$ according to Alho et al., 1989; and from $47.1 \mathrm{Kg} / \mathrm{Km}^{2}$ according to Schaller, 1983 to $338 \mathrm{Kg} / \mathrm{Km}^{2}$ according to Schaller \& Crawshaw, 1981) and in the natural savannas of Apure, Venezuela (respectively, 60 to 103 individuals $/ \mathrm{Km}^{2}$ and 1800 to $3090 \mathrm{Kg} / \mathrm{Km}^{2}$ according to Ojasti, 1973). However, Herrera (1986) found higher ecological densities in Venezuela than we did in our present study (200 individuals $/ \mathrm{Km}^{2}$ or $6000 \mathrm{Kg} / \mathrm{Km}^{2}$ ).

Extensive wetlands such as the Venezuelan Llanos and the Brazilian Pantanal differconsiderably from wetlands in southeastern Brazil, which are generally small and relatively isolated from each other. Capybaras have a strong affinity for water, which they use for mating and to avoid predators. In addition, the species forages in open fields rather than in the forest (Escobar \& González-Jiménez, 1976; Schaller, 1983). The presence of grasslands with a more abundant food supply can result in a larger number of adults or in larger groups (Herrera, 
TABLE 2

Observers' bias in capybara counts according to their distance from animals.

Observers

\begin{tabular}{|c|c|c|c|c|c|}
\hline & & 1 & 2 & 3 & $P$ \\
\hline \multirow{4}{*}{$\begin{array}{l}\text { Site } 1 \\
(50 \text { to } 100 \mathrm{~m})\end{array}$} & Total population & $\mathrm{a}$ & $\mathrm{a}$ & $\mathrm{b}$ & 0.001 \\
\hline & Adults & $\mathrm{a}$ & $\mathrm{a}$ & $\mathrm{b}$ & 0.000 \\
\hline & Juveniles & $\mathrm{a}$ & $\mathrm{a}$ & $\mathrm{a}$ & 0.922 \\
\hline & Young & $\mathrm{a}$ & $\mathrm{a}$ & $\mathrm{a}$ & 0.685 \\
\hline \multirow{4}{*}{$\begin{array}{l}\text { Site } 2 \\
(10 \text { to } 50 \mathrm{~m})\end{array}$} & Total population & $\mathrm{a}$ & $\mathrm{a}$ & $\mathrm{b}$ & 0.000 \\
\hline & Adults & $\mathrm{a}$ & $\mathrm{a}$ & $\mathrm{a}$ & 0.788 \\
\hline & Juveniles & $\mathrm{a}$ & $\mathrm{a}$ & $\mathrm{a}$ & 0.690 \\
\hline & Young & $\mathrm{a}$ & $\mathrm{a}$ & $\mathrm{a}$ & 0.318 \\
\hline \multirow{4}{*}{$\begin{array}{l}\text { Site } 3 \\
(<10 \mathrm{~m})\end{array}$} & Total population & $\mathrm{a}$ & $\mathrm{a}$ & $\mathrm{a}$ & 0.587 \\
\hline & Adults & $\mathrm{a}$ & $\mathrm{a}$ & $\mathrm{a}$ & 0.898 \\
\hline & Juveniles & $\mathrm{a}$ & $\mathrm{a}$ & $\mathrm{a}$ & 0.588 \\
\hline & Young & $\mathrm{a}$ & $\mathrm{a}$ & $\mathrm{a}$ & 0.861 \\
\hline
\end{tabular}

$\mathrm{a}>\mathrm{b}$ (for Confidence interval $=95 \%$ ).

1986; Herrera \& Macdonald, 1989), as in the case of other social mammals (Bergerud, 1971; Krebs, 1985). This emphasizes the importance of the interaction between open areas and water bodies (i.e., their proximity) in terms of habitat quality for the species (as suggested by Ojasti, 1973; Macdonald, 1981; Herrera \& Macdonald, 1989) even in small areas.

This species is a generalist herbivore whose feeding habits possibly facilitate its occurrence in anthropogenic habitats such as agroecosystems, which offer a more abundant food supply, similarly to what has been suggested for other species (Lacher et al., 1999). The local extinction of large predators in such conditions may also have resulted in cases of dramatic population increase and crop damage by herbivores (Ferraz et al., 2003).

Capybaras can be less detectable in forest than in open areas, which may affect observer's efficiency (Lehner, 1996). However, in the present study, discrepancies among observers were related to their distance from the animals, even in open areas. At the intermediate distance, observers' counts showed significant variations only in terms of the total population but not specifically for any age class. The observers' counts showed no significant differences when their distance from animals was the smallest, indicating that increasing distances from animals can lead to higher counting errors.
The variation in the abundance index for the total study period suggests that the population's annual cycle resembles that suggested by Schaller (1983), but year-to-year variations may be considerable. However, there seems to be a peak in late spring (Oct to Dec). This pattern appears to be clear not only for the total population but also specifically for the age classes. In the future, we expect to analyze population cycles over several years, taking into account habitat features and seasonality.

The population fluctuation models for 1999 show a consistent difference among age classes. Contrary to the fluctuation of the total population as well as of adults and juveniles, which presented a clearly similar asymptotic curve, the young presented a quadratic model. The decline in young numbers after the peak may be explained by either their mortality or growth and their consequent reclassification as juveniles by observers in subsequent counts (see Fig. 1). Capybaras usually take six to twelve months to develop from young to juveniles and from there to adults (Lavorenti, 1989).

The model for the total population presented a very similar estimated carrying capacity (195 individuals $/ \mathrm{Km}^{2}$ ) to the density found by Herrera (1986) (200 individuals/ $\mathrm{Km}^{2}$ ), and approximately 1.89 to 3.25 times the density of capybaras in Venezuela (considering Ojasti, 1973), 
2.82 to 195 times that of the Brazilian Pantanal (considering Alho et al. 1989), and 1.95 times the estimated optimal average density suggested by Herrera \& Moreira (1996) for the Brazilian Amazon and by Hoogesteijn \& Chapman (1997) for the Venezuelan llanos.

Although the present study covered a relatively short period, it was possible to fit the population fluctuation curve into a mathematical model by a time series analysis that allows for forecasting. Fitting the 1999 data to an asymptotic model provided a reasonable estimate of the study site's carrying capacity $(\mathrm{k})$.

The growth rate ( 0.89$)$ estimated by the model for the total population in 1999 was approximately $30 \%$ higher than the intrinsic rate of natural increase of capybaras on Marajó Island estimated by Herrera \& Moreira (1996). However, considering the accuracy of such studies, it is unlikely that these values differ significantly. This value could possibly be used as such in sustainable use models (e.g., Robinson \& Redford, 1991). However, we did not use this model here because ecological variables such as age at sexual maturity, litters per year and other factors are yet to be determined for the population in question. The surprisingly high values reported here indicate that agroecosystems may support a considerably higher population density than those found in pristine habitats. This fact should be taken into account in both damage control and harvest programs.

In cases of damage caused by the species, farmers and ranchers usually request a control program. However, considering that the capybara is a native species whose meat and leather have an economic potential (Ojasti, 1991), such programs should not aim at its local extinction. Instead, the species should be managed at a sustainable level, as suggested by Begon \& Mortimer (1996), Caughley (1977), and Caughley \& Sinclair (1994). Such programs should be based on periodic (e.g., annual) population monitoring and on assessments of the maximum sustainable yield (Robinson \& Redford, 1991; Magnusson, 1993; Mourão 1999), which are related to the abundance and productivity of the species in the area (Moreira \& Macdonald, 1997). In this study, we estimated productivity as the biomass $(\mathrm{Kg})$ harvested per area $\left(\mathrm{Km}^{2}\right)$ per year, as suggested by Eisenberg et al. (1979).
Considering a theoretical exploitation rate (i.e., hunting quota) of $17 \%$ of the population (as suggested by Moreira \& Macdonald 1997 for Marajó Island in the Brazilian Amazon), it would be possible to harvest approximately 21 adult individuals $/ \mathrm{Km}^{2} /$ year in the present study area. Assuming an individual average body mass of $30 \mathrm{Kg}$ (as suggested by Eisenberg et al., 1979; Schaller 1983), it would be possible to harvest approximately $630 \mathrm{Kg} / \mathrm{Km}^{2} /$ year on the main wetlands of the "Luiz de Queiroz" campus. The minimum estimated value is similar to the one estimated in Venezuela $\left(244 \mathrm{Kg} / \mathrm{Km}^{2} /\right.$ year$)$ by Kleiman et al. (1979) for previous data (Ojasti, 1973) at a slightly higher harvest rate (20\%). However, the maximum estimated value is lower than that proposed by Moreira \& Macdonald (1996) for the Brazilian Amazon $\left(841 \mathrm{Kg} / \mathrm{Km}^{2} /\right.$ year) at the same harvest rate $(17 \%)$, possibly because in their model they consider harvesting at the maximum sustainable yield, which is ecologically unsafe (Caughley \& Sinclair, 1994).

\section{CONCLUSIONS}

- The population density and biomass of capybaras in anthropogenic wetlands can be significantly higher than in pristine habitats;

- In southeastern Brazil, capybara populations seem to present a seasonal pattern of fluctuation with a peak in late spring (Oct to Dec);

- The distance between observers and animals may result in counting biases, even in open habitats;

- Adults and juveniles present similar seasonal fluctuation patterns that differ from those of the young;

- The carrying capacity in anthropogenic wetlands of southeastern Brazil may be as high as 195 individuals $/ \mathrm{Km}^{2}$; and

- At a conservative exploitation rate (17\%) in anthropogenic wetlands of southeastern Brazil, capybaras can produce approximately $630 \mathrm{Kg} / \mathrm{Km}^{2} /$ year.

Acknowledgments - This study was partially supported by Fundação de Amparo à Pesquisa do Estado de São Paulo - FAPESP (Process No 00/00180-9, No 00/00602-0, and $\mathrm{N}^{\circ}$ 00/00582-0). We are indebted to Prof. Marcos Folegatti and the "Luiz de Queiroz" campus administration/USP for their enthusiasm and support. We also would like to thank the students Allan Veltrone, Ana Paula A. Santos, Cristiane G. Caldana, Felipe Spina, Gustavo R. M. Pinto, Roberto M. F. 
Santos-Filho, and Társis R. O. Piffer for their participation in the field work.

\section{REFERENCES}

ALHO, C. J. R., CAMPOS Z. M. \& GONÇALVES, H. C., 1989, Ecology, social behaviour and management of the capybara in the Pantanal of Brazil, pp. 163-194. In: K. H. Redford \& J. F. Eisenberg (eds.), Advances in Neotropical Mammalogy, Sandhill Crane Press, Gainesville, Florida, USA.

AZCÁRATE, T., 1980, Sociobiologia y manejo del capibara (Hydrochoerus hydrochaeris). Doñana Acta Vertebrata, 7(6): 1-228.

BEGON, M. \& MORTIMER, M., 1996, Population Ecology. A Unified Study of Animals and Plants. Second edition. Blackwell Scientific Publications, Oxford, UK, 220p.

BERGERUD, A. T., 1971, The role of the environment in the aggregation, movement and disturbance behaviour of caribou, pp. 552-584. In: V. Geist \& F. Walther (eds), The Behavior of Ungulates and its Relation to Management, International Union for the Conservation of Nature and natural Resources, Morges, Switzerland.

BROWN, D. \& ROTHERY, P., 1993, Models in Biology: Mathematics, Statistics and Computing. John Wiley \& Sons, Chichester, England, 708p.

CAUGHLEY, G., 1977, Analysis of vertebrate populations. John Wiley \& Sons, Chichester, UK, 234p.

CAUGHLEY, G. \& SINCLAIR, A. R. E., 1994, Wildlife Ecology and Management. Blackwell Science Publications, Boston, USA, 334p.

CONROY, M. J., 1996, Abundance indices, pp. 179-192. In: D. E. Wilson, F. R. Cole, J. D. Nichols, R. Rudran \& M. S. Foster (eds.), Measuring and monitoring biological diversity: Standard Methods for Mammals. Smithsonian Institution, Washington, D.C., USA, 480p.

CORDERO, G. A. \& OJASTI, J., 1989, Comparison of capybara populations of open and forested habitats. Journal of Wildlife Management, 45(1): 267-271.

EISENBERG, J. F. \& SEIDENSTICKER, J., 1976, Ungulates in southern Asia: a consideration of biomass estimates for selected habitats. Biological Conservation, 10: 293-308.

EISENBERG, J. F. \& REDFORD, K. H., 1999, Mammals of the Neotropics: The Central Neotropics. University of Chicago, Chicago, Illinois, USA, $2^{\circ}$ vol., 430p.

EISENBERG, J. F., O'CONNELL, M. A. \& AUGUST, P. V., 1979 , Density, productivity and distribution of mammals in two Venezuelan habitats, pp. 187-207. In: J. F. EISENBERG (ed.). Vertebrate Ecology in the Northern Neotropics. Smithsonian Institution, Washington, D. C., USA, 614p.

ESCOBAR, A. \& GONZÁLEZ-JIMÉNEZ, E., 1976, Estudio de la competencia alimenticia de los herbívoros mayores del llano inundable con referencia especial al chigüire ( $\mathrm{Hy}$ drochoerus hydrochaeris). Agronomia Tropical, 26(3): 215227.

FERRAZ, K. P. M. B., LECHEVALIER, M. A., COUTO, H. T. Z. \& VERDADE, L. M., 2003, Damage caused by capybaras on a corn field. Scientia Agricola, 60(1): 191-194.
GONZALEZ-JIMENEZ, E., 1984, Capibara, pp. 258-259. In: I. L. MASON (ed.). Evolution of domesticated animals. Longman, London, UK, 454p.

GREENWOOD, J. J. D., 1996, Basic techniques. pp. 11-110. In: W. J. SUTHERLAND (ed.) Ecological Census Techniques: A Handbook. Cambridge University, Cambridge, UK, 336p.

HERRERA, E. A., 1986, The behavioural ecology of capybara, Hydrochoerus hydrochaeris. Dissertation, University of Oxford, Oxford, UK.

HERRERA, E. A. \& MACDONALD, D. W., 1989, Resource utilization and territoriality group-living Capybaras (Hydrochoerus hydrochaeris). Journal of Animal Ecology, 58: 667-679.

HERRERA, E. \& MOREIRA, J. R., 1996, Capybaras - giant rodents with a giant potencial, pp. 181-186. In: D. Macdonald \& F. H. Tattersall (eds.). The WildCru Review. The Wildlife Conservation Research Unit, Oxford University, Oxford, UK.

HOOGESTEIJN, R. \& CHAPMAN, C. A., 1997, Large ranches as conservation tools in the Venezuelan llanos. Oryx, 31: $274-284$.

JORGENSON, J. P., 1986, Notes on the ecology and behavior of capybaras in northeastern Colombia. Vida Silvestre Neotropical, 1(1): 31-40.

KLEIMAN, D. G., EISENBERG, J. F. \& MALINIAK, E., 1979, Reproductive parameters and productivity of caviomorph rodents, pp. 173-183. In: J. F. Eisenberg (ed). Vertebrate Ecology in the Northern Neotropics. Smithsonian Institution, Washington, USA, 614p.

KREBS, C. J., 1985, Ecology: The Experimental Analysis of Distribution and Abundance, Third edition. Harper Collins, New York, USA, 800p.

LACHER, T. E., JR., SLACK, R. D., COBURN, L. M. \& GOLDSTEIN, M. I., 1999, The role of agroecosystems in wildlife biodiversity, pp. 147-165. In: W. W. Collins \& C. O. Qualset (eds). Biodiversity in Agroecosystems. CRC, Boca Raton, FL, USA, 352p.

LANCIA, R. A, NICHOLS, J. D. \& POLLOCK, K. H., 1996, Estimating the number of animals in wildlife populations, pp. 215-253. In: T. A Bookhout (ed.), Research and Management Techniques for Wildlife and Habitats. Fifth edition. The Wildlife Society, Maryland, USA, 740p.

LAVORENTI, A., 1989, Domestication and potential for genetic improvement of capybara. Revista Brasileira de Genética, 12(3): 137-144.

LEHNER, P. N., 1996, Handbook of Ethological Methods. Second edition. Cambridge University, Cambridge, UK, 403p.

LORD, R. D., 1994, A descriptive account of capybara behaviour. Studies on Neotropical Fauna and Environment, 29: 11-22.

LORD, R. D. \& LORD, V. R., 1988, Cross checking censuses and a model of the annual cycle of mortality and reproduction in capybaras. Studies on Neotropical Fauna and Environment, 23(4): 213-224.

MACDONALD, D. W., 1981, Dwindling resources and the social behaviour of capybara, (Hydrochoerus hydro- 
chaeris) (Mammalia). Journal of Zoological of London, 194: 371-391.

MACDONALD, D. W., 1999, Encyclopedia of Mammals. Facts on File, New York, USA. 895p.

MAGNUSSON, W. E., 1993, Manejo de vida silvestre na Amazônia, pp. 313-318. In: E. J. G. Ferreira, G. M. Santos \& L. A. Oliveira (eds), Bases Científicas para Estratégias de Preservação e Desenvolvimento da Amazônia. $2^{\circ}$ vol., 895p, Instituto Nacional de Pesquisas da Amazônia, Manaus, AM, Brasil.

MINITAB, 2000, Minitab for Windows Release 13. Minitab, Inc., State College, PA, USA., 907p.

MOREIRA, J. R. \& MACDONALD, D. W., 1996, Capybara use and conservation in South America, pp. 88-101. In: V. J. Taylor \& N. Dunstone (eds.), The exploitation of mammal populations. Chapman \& Hall, London, UK, 415p.

MOREIRA, J. R. \& MACDONALD, D. W., 1997, Técnicas de manejo de capivaras e outros grandes roedores na Amazônia, pp. 186-213. In: C. VALLADARES-PADUA, R. E. BODMER \& L. CULLEN JR. (eds.), Manejo $e$ Conservação de Vida Silvestre no Brasil. Sociedade Civil Mamirauá, Belém, PA, Brasil, 285p.

MOURÃO, G. M., 1999, Uso comercial da fauna silvestre no Pantanal: lições do passado, pp. 39-45. In: Anais do II Simpósio sobre Recursos Naturais e Sócio-econômicos do Pantanal: Manejo e Conservação. Embrapa, Corumbá, MS, Brasil.
MOURÃO, G. M. \& CAMPOS, Z. M., 1995, Survey of broadsnouted caiman Caiman latirostris, marsh deer Blastocerus dichotomus and capybara Hydrochoerus hydrochaeris in the area to be inundated by Porto Primavera dam, Brazil. Biological Conservation, 73: 27-31.

MURRAY, J. D., 1993, Mathematical Biology. Second edition. Springer-Verlag, Berlin, Germany, 767p.

OJASTI, J., 1973, Estudio Biológico del Chigüire o Capibara. Fondo Nacional de Investigaciones Agropecuarias, Caracas, Venezuela, 275p.

OJASTI, J., 1991, Human exploitation of capybara, pp. 236-252. In: J. G. Robinson \& K. H. Redford (eds.), Neotropical Wildlife Use and Conservation. The University of Chicago Press, Chicago, USA, 520p.

ROBINSON, J. G. \& K. H. REDFORD, 1991, Sustainable harvest of neotropical forest animals, pp. 415-429. In: J. G. Robinson \& K. H. Redford (eds.), Neotropical Wildlife Use and Conservation. The University of Chicago Press, Chicago, USA, 520p.

SCHALLER, G. S., 1983, Mammals and their biomass on a Brazilian ranch. Arquivos de Zoologia, 31(1): 1-36.

SCHALLER, G. S. \& CRAWSHAW, P. G., 1981, Social organization in a capybara population. Säugetierkundliche Mitteilungen, 29: 3-16.

SOKAL, R. R. \& ROHLF, F. J., 1995, Biometry. Third edition. W. H. Freeman, New York, USA, 363p.

ZAR, J. H., 1996, Biostatistical Analysis. Third edition. Prentice Hall. Upper Saddle River, NJ, USA, 662p. 